\title{
Considerations for a revision of the fern family Vittariaceae for Flora Malesiana
}

\author{
Stuart Lindsay
}

\begin{abstract}
Lindsay, S. (Arnold Arboretum \& Harvard University Herbaria, 22 Divinity Avenue, Cambridge, MA 02138, USA) 2003. Considerations for a revision of the fern family Vittariaceae for Flora Malesiana. Telopea 10(1): 99-112. The Vittariaceae is a family of mostly tropical epiphytic or lithophytic fern species. The family is particularly well represented in Malesia but the number of species present and the genera in which they should be recognised is currently uncertain. This paper explains why. Three factors are discussed: the impact of new molecular data on the traditional concepts of genera in the Vittariaceae; the uncertain taxonomic position of the monotypic (and Malesian endemic) genus Rheopteris; and the possibility that unrecorded species, including undescribed ones, exist within the region only as gametophytes.
\end{abstract}

\section{Introduction}

A monographic revision of the fern family Vittariaceae is long over-due. The only monograph in existence is that prepared by Fée and published in 1852 as parts $3 \& 4$ of his Mémoires sur la Famille des Fougères. Part 3 (Fée 1852a) describes c. 60 species (and c. 70 synonyms) of Vittariaceae while part 4 (Fée 1852b) describes c. 25 species (and c. 40 synonyms) of Antrophyum. Fée's monograph (which also includes superb illustrations of 27 species) is, undeniably, an impressive account of almost all the Vittariaceae known in the mid-19th century but it cannot now be regarded as representing anything close to a comprehensive treatment of the family. Over the last 150 years or so, c. 220 new species have been described for the family, c. 140 new name combinations have been made, and almost half of the species recognised as Vittariaceae by Fée have been moved to, and accepted in, other fern families (see Index Filicum by Christensen 1905-1906, and its seven supplements: Christensen 1913, 1917, 1934; Pichi-Sermolli 1965; Jarrett 1985; Johns 1996, 1997). In total, more than 550 species names have been assigned to various concepts of the Vittariaceae but the family, as recognised today, probably contains no more than 100-130 species.

Species of Vittariaceae are most strongly represented in the damp forests of the New and Old World Tropics (including many islands of the Pacific but not really including tropical Africa where the family is relatively poorly represented). Although the majority of species are tropical, a significant number of species can be found outside the tropics, in places such as south-eastern United States, Argentina, Tristan da Cunha, Easter Island, South Africa, Nepal, China, South Korea and Japan. According to Kramer (1990), the Vittariaceae appear to be a somewhat isolated, very natural (but see discussion of Rheopteris later in this paper) group of leptosporangiate ferns, as a whole now well adapted to an epiphytic or lithophytic habitat and therefore probably of secondarily much simplified structure. All of them possess creeping rhizomes (not immediately obvious in some short-creeping species) on which the fronds (usually pendulous, because they lack sclerenchyma) are usually arranged in two rows on the dorsal surface. The fronds of most species are simple and have reticulate venation, but in a few species in which the frond laminae have become much reduced the venation 
consists simply of a mid-rib with or without a few, free, lateral veins. An interesting feature, which (along with the lack of sclerenchyma) has proved to be a valuable diagnostic character for the family, is the presence of spicule cells (elongated idioblasts containing needle-like crystals; perhaps of silica) in the epidermis of the fronds (Williams 1927). The sporangia are fairly constant in form throughout the family and in most species are assembled in simple or branched soral lines. These soral lines usually also contain paraphyses, the presence/absence, shape or colour of which can be characteristic of certain species or species groups (e.g. Fée 1852a, 1852b; Benedict 1907; Shaffer-Fehre 1996). Little is known about the gametophytes of the Vittariaceae but those of the few species that have been investigated (actually 18 species; $12 \mathrm{New}$ World; 6 Old World) are ribbon-shaped and perennial (gametophytes of most fern species are heart-shaped and short-lived) and all, except one species, bear filamentous gemmae (also rare in ferns) with which they can propagate themselves asexually (Atkinson \& Stokey 1964; Nayar \& Kaur 1969, 1971; Farrar 1974, 1985; Emigh \& Farrar 1977; Sheffield \& Farrar 1988). The morphology and ecology of the gametophytes of Vittariaceae are discussed in more detail later in this paper.

\section{Generic delimitation}

\section{Traditionally recognised genera}

The uniform and simple morphology exhibited by the sporophytes of the Vittariaceae has offered taxonomists few characters useful for classification; disagreement over the interpretation of the few available characters has resulted in the recognition by different authors of between five and 10 genera (e.g. Benedict 1911; Williams 1927; Copeland 1947; Tryon \& Tryon 1982; Kramer 1990). That said, most modern texts do agree, at least, with the recognition of five or six main genera based largely on differences in the size and shape of fronds, venation, and soral arrangement. These five or six genera (in order of increasing size) (see Kramer 1990) are: Rheopteris Alston (recognised after 1956); Anetium (Kunze) Splitg.; Hecistopteris J.Sm.; Monogramma Comm. ex Schkuhr; Antrophyum Kaulf.; and Vittaria Sm.

Rheopteris, as currently recognised, is a monotypic genus confined to New Guinea; the single species Rheopteris cheesmaniae Alston shares certain characters with other members of the Vittariaceae (e.g. spicule cells), but other characters (especially the pinnate fronds, free venation, and round sori) are so atypical of Vittariaceae that the taxonomic position of Rheopteris, and its current inclusion in Vittariaceae, demands further investigation (Rheopteris is discussed in more detail later in this paper because of its significance to the generic framework of the Vittariaceae in Malesia).

Anetium is also a monotypic genus; its only species Anetium citrifolium (Kunze) Splitg. is widespread in tropical America. Anetium citrifolium deviates somewhat from typical Vittariaceae in that the sporangia are not (or are only partially) arranged in soral lines.

Until relatively recently, Hecistopteris was also considered to be a monotypic genus widespread in tropical America. However, a second species, currently only known from Ecuador, was described in 1995 (Moran \& Øllgaard 1995) and a third species, currently only known from Guyana was described in 1998 (Kellof \& McKee 1998). All three species are minute, easily over-looked, epiphytes with fronds that deviate somewhat from typical Vittariaceae in having forked or cleft laminae and dichotomously branched veins. 
Monogramma, in its broadest sense, is a genus of eight species found in the warmer parts of the Old World, particularly the east-African islands, Sri Lanka, and the Malesian and Pacific regions. Like Hecistopteris, most species of Monogramma are also minute, easily overlooked epiphytes. It is in this genus (and to a lesser extent in Vittaria) that frond laminae can become so reduced that venation consists simply of a mid-rib. Although not universally accepted, the genus Monogramma is sometimes split into two genera: Monogramma s.s., for the two species in which the venation consists simply of a mid-rib, and Vaginularia Fée, for the six species in which the venation consists of a mid-rib plus a few (albeit, often indistinct) lateral veins.

Vittaria and Antrophyum have always been regarded as the two main genera within Vittariaceae. The size of each of these genera has never been properly established; published estimates of species numbers range from 50-150 for Vittaria and from 40-80 for Antrophyum. Vittaria (as recognised by most botanists in the 20th century, prior to being re-defined by Crane et al. (1995) and Crane $(1995,1997)$ - see below) is a genus of tropical (mostly), or warm-temperate species, many of which are not clearly defined. The generic name is derived from the Latin word 'vitta', meaning 'ribbon', an allusion to the ribbon-like shape of the fronds of most species. Species of Vittaria are also commonly referred to as 'Shoestring Ferns', 'Tape Ferns' or 'Grass Ferns'. Vittaria is widely acknowledged to be a difficult and confused genus in need of a thorough revision (e.g. Kramer 1990). In addition to having characteristic ribbon-like fronds, species of Vittaria are also usually characterised by a pair of long, continuous soral lines, often immersed in grooves in the laminae or covered by the reflexed unmodified leaf margin. Although not universally accepted, the genus Vittaria has, sometimes, been split into smaller genera or subgenera. Benedict $(1911,1914)$ proposed the recognition of two subgenera: subgenus Radiovittaria for species with (sub)erect radial stems (all American) and subgenus Vittaria for those without (sub)erect radial stems. Maxon (1908) proposed that one Vittaria species with particularly unusual venation (Vittaria angustifolia (Sw.) Baker; the only Vittaria with pluriseriate venation, instead of biseriate venation) should become the sole member of the monotypic genus Ananthacorus. Ananthacorus angustifolius (Sw.) Underw. \& Maxon (which is still often known by the synonym Vittaria costata Kunze, e.g. Moran 1995) is widespread in tropical America.

Antrophyum (as recognised by most botanists in the 20th century, prior to being redefined by Crane et al. (1995) and Crane (1995, 1997) - see below) is a genus of tropical or warm-temperate species best represented in south-east Asia. Fronds of Antrophyum are similar in shape to those of Anetium, but in Antrophyum the sporangia are arranged along the reticulate veins in such a way that the soral lines may join to form a 'soral net'. Many species of Antrophyum are ill-defined and this genus is also in need of a thorough revision (Kramer 1990). There have been suggestions (e.g. Moore 1857; Benedict 1907, 1911; Christensen 1925) that the genus Antrophyum should be split into several smaller genera or subgenera but, as in Vittaria, the proposed subdivisions have not been universally accepted. The four subgenera proposed by Benedict in 1907 were: Antrophyum s.s., for species with tetrahedral spores in which the costa evanesce above the base and in which there are paraphyses amongst the sporangia in the soral lines (only Old World species have this combination of characters); Polytaenium (Desv.) Benedict for species with tetrahedral spores in which veins originate from a full-length mid-rib (percurrent costa) and in which there are no paraphyses amongst the sporangia in the soral lines (only New World species have this combination of characters); Scoliosorus (T.Moore) Benedict for one fairly widespread New World species (Antrophyum ensiforme Hook.) with, among other unusual characters, bilateral spores and paraphyses; and Antrophyopsis Benedict for four African 'species' (nowadays recognised as Antrophyum mannianum Hook. and three varieties of Antrophyum boryanum (Willd.) Spreng.) also with bilateral spores and paraphyses. 
Christensen (1925) proposed another subgenus, Bathia C.Chr, for three species in Madagascar (unknown to Benedict) that not only have bilateral spores and paraphyses but which, in general morphology and anatomy, are somewhat intermediate between Antrophyum and Vittaria.

\section{The impact of new molecular characters}

The previous section summarized the intrafamilial taxonomy of the Vittariaceae as it was understood in the early 1990's, a few years before the start of the 'molecular revolution' in fern systematics. In 1995, a group of researchers at Iowa State University, U.S.A., published the results of the first (and as yet, only) phylogenetic analysis of $r b c \mathrm{~L}$ gene sequences from 22 species of Vittariaceae (Crane et al. 1995). Despite a bias towards New World species (the material they found easiest to obtain), their analysis clearly indicated that Vittaria and Antrophyum (as each has traditionally been recognised on the basis of sporophyte morphology) are, respectively, polyphyletic and paraphyletic. This new information could have significant implications for the future classification and content of these genera and the family as a whole. Indeed, by further analyzing their molecular data, Crane et al. managed to re-organize their 22 study species into nine groups (putative 'genera') that were strictly monophyletic (Figure 1).

On the basis of this, and the discovery that the topology of the tree based on $r b c \mathrm{~L}$ sequence data was also well supported by four morphological characters (spore type: tetrahedral or bilateral; shape of the terminal cell on the soral paraphyses: absent, slender, funnel-shaped or round; pattern of gemma development: absent, produced singly or produced in inter-connecting pairs; and the arrangement of the fronds on the rhizome: distichous phyllotaxy or polystichous phyllotaxy) Crane (1997) proposed a revised circumscription of the genera within Vittariaceae (10 or 11 in his opinion) and gave new combinations for 30 species. Of the six main genera traditionally recognised in Vittariaceae on the basis of sporophyte morphology (outlined in the previous section), Rheopteris, Anetium, Hecistopteris and Monogramma remain unchanged (Rheopteris and Monogramma were not included in Crane's molecular study). Antrophyum (as traditionally recognised) was split into three genera: Antrophyum s.s., containing only Old World species; Polytaenium, containing only New World species; and Scoliosorus, a small genus containing two Old World (African) species and one New World species. Thus the new molecular characters generated by Crane et al. provided additional support for the earlier suggestions of Benedict (and others) that Old and New World species of Antrophyum s.l. are different, and that within the Old World the African and Asian species are also different.

Perhaps the most interesting and novel piece of information to come out of this study in relation to Antrophyum s.l. is the apparent relationship of the unusual New World species Antrophyum ensiforme Hook., (Benedict's subgenus Scoliosorus), with the two African species Antrophyum boryanum (Willd.) Spreng. and Antrophyum mannianum Hook. (Benedict's subgenus Antrophyopsis). Benedict was clearly aware of certain similarities between these species (especially in relation to their spores and paraphyses), but there is no evidence in the literature that he had contemplated a close relationship between Antrophyum ensiforme in America and the other two species in Africa.

Vittaria (traditionally recognised as the largest genus in the Vittariaceae and pantropical) was also split by Crane into three genera: Vittaria s.s. was re-defined as a very small genus containing only six species, five of which are confined to the New World. The exception, Vittaria isoetifolia Bory, is confined to Africa and the eastAfrican islands. All the New World species formerly recognised as 'Vittaria' but now 


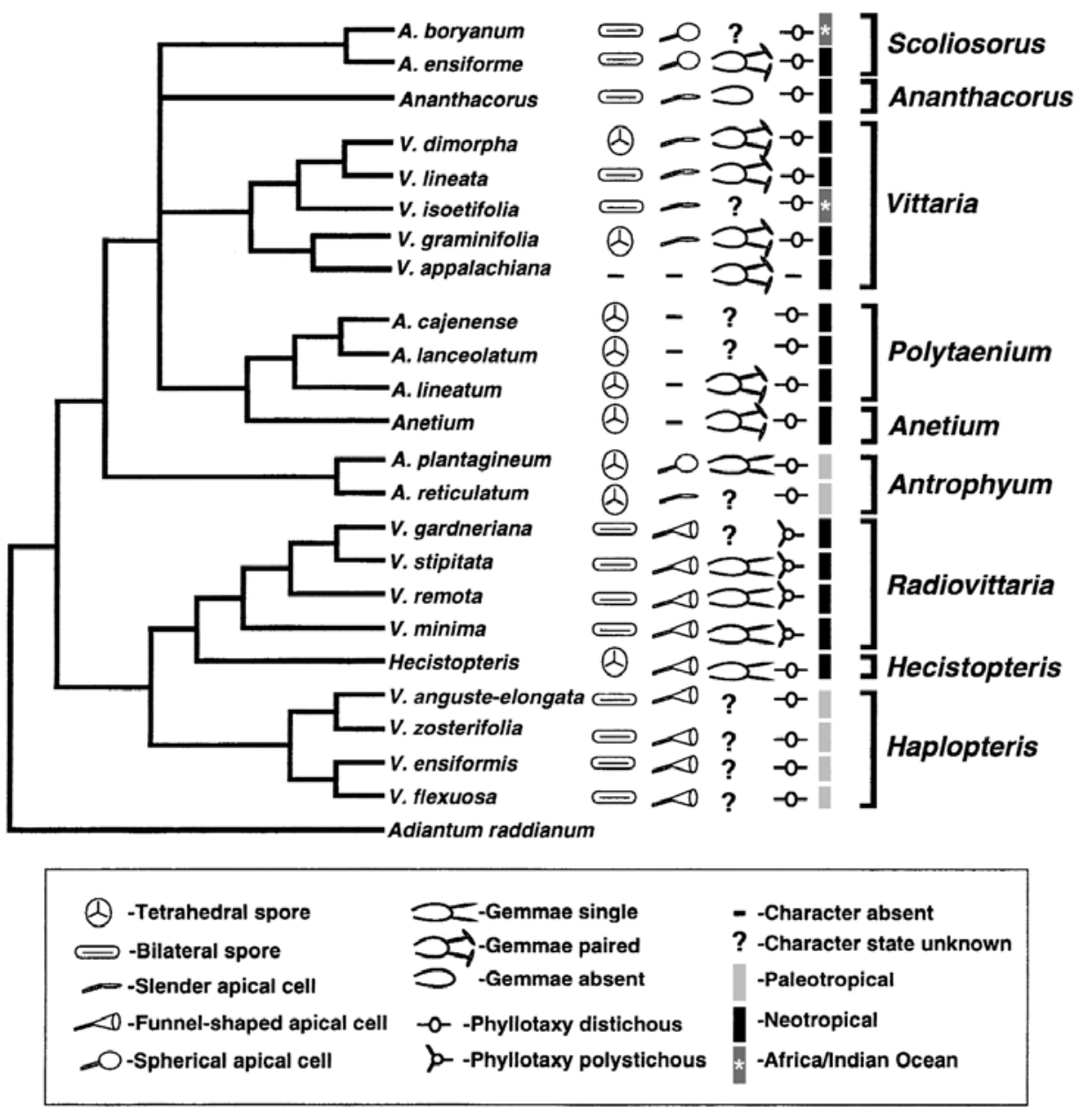

Fig. 1. A strict consensus tree resulting from phylogenetic analysis of $r b c L$ gene sequences from 23 species of Vittariaceae (adapted from Crane et al. 1995 and Crane 1997). Symbols showing the states of four morphological characters are mapped onto the tree. These characters (and their states) are: spore type (tetrahedral or bilateral); shape of the apical cell on the soral paraphyses (absent, slender, funnel-shaped or spherical); pattern of gemma development (absent, produced singly or produced in inter-connecting pairs); and the arrangement of the fronds on the rhizome (distichous phyllotaxy or polystichous phyllotaxy). The blocks to the right of the morphology symbols indicate the geographical distribution of each species. Brackets to the far right indicate the revised generic circumscription of Vittariaceae proposed by Crane. Note: (1) The consensus trees shown in Crane et al. (1995) show only 22 species of Vittariaceae because $r b c L$ sequence data for Vittaria appalachiana was not incorporated into the analysis until a later date. The explanation for why sporophytic morphological characters are absent in this species is given in the 'Independent gametophytes' section of this paper. (2) At the time of Crane's initial molecular analysis Hecistopteris was believed to be a monotypic genus; accordingly the label 'Hecistopteris' in Figure 2 refers to Hecistopteris pumila (Spreng.) J.Sm. 
excluded from it were placed in the genus Radiovittaria. This was the first time that this name had been used at the generic level, but the content of this genus (except for the inclusion of one additional species) is no different from that of subgenus Radiovittaria proposed by Benedict almost 90 years ago.

The third segregate genus of Vittaria recognised by Crane was Haplopteris. In contrast to Radiovittaria, this was not the first time that this name had been used at the generic level in Vittariaceae but its previous use was extremely brief and a long time ago (predating but not appearing in Fée's monograph of 1852). Haplopteris was resurrected and re-defined by Crane to accommodate nearly all the Old World species formerly recognised as 'Vittaria'. Eleven of the 20 species that have already been moved to Haplopteris are Malesian.

\section{The genus Rheopteris}

Another factor that must be considered when deciding on the generic framework of the Vittariaceae in the Flora Malesiana region is the currently uncertain taxonomic position of the genus Rheopteris Alston. Rheopteris, as currently defined, is a monotypic genus known from only three collections in the mountains of West Sepik Province, Papua New Guinea. The genus and its only species, Rheopteris cheesmaniae Alston, were described in 1956 based on examination of a specimen (at BM) collected by L.E. Cheesman in the Toricelli Mountains in 1939 (Alston 1956). The other two collections were made by J. Croft et al. in 1982 during a PNG National Herbarium (LAE) Botanical Expedition to the Bewani Mountains (approximately $100 \mathrm{~km}$ west of the original collecting locality). Since $R$. cheesmanie was described there has been considerable uncertainty as to what its closest relatives might be. In spite of this, and the fact that Alston himself did not propose a family for his genus, most workers have (albeit, with some reservations) placed Rheopteris in Vittariaceae (e.g. Kramer 1990; Tryon \& Lugardon 1990; Brummitt 1992).

A revision of the Vittariaceae for Flora Malesiana requires that evidence must be produced to either keep Rheopteris in Vittariaceae or exclude it. Anatomical and morphological features including spicular cells, clathrate scales, soral paraphyses, smooth spores, and the absence of indusia do suggest a relationship with Vittariaceae, but the stiff, erect, simply pinnate fronds - with pinnae superficially resembling those of species in the genus Lindsaea (Alston 1956) - and circular sori (Figure 2) are distinctive characters not shared with any other species currently recognised in Vittariaceae. Rheopteris cheesmaniae also has free veins, a relatively rare character in Vittariaceae.

Resolution of the taxonomic problem surrounding $R$. cheesmaniae would undoubtedly be made a lot easier if the species could be relocated in the wild and frond and viable spore material were collected for laboratory and glasshouse studies. It would be fascinating to see the results of an improved molecular phylogeny of the Vittariaceae that included Rheopteris (as well as the two other Old World genera of Vittariaceae missing from Crane's study: Monogramma and Vaginularia). Studies on the morphology and development of the gametophytes and gemmae (if any?) of $R$. cheesmaniae would also be of particular interest, given the significant correlation of gametophytic and molecular characters demonstrated in Crane's study (Figure 1). Additional field observations of adult plants are also required to provide a more accurate and complete description of $R$. cheesmaniae, the size and growth habit of the sporophyte, and the ecology of both generations. Alston described Cheesman's plant as an 'epiphyte' with a 'creeping rhizome', but as her largest rhizome fragment is only $4 \mathrm{~cm}$ long, nothing much can be deduced about its original length or branching pattern. The label of Croft 1749 (duplicate at A with rhizome fragment $7.5 \mathrm{~cm}$ long) states '... climbing fern ...' 


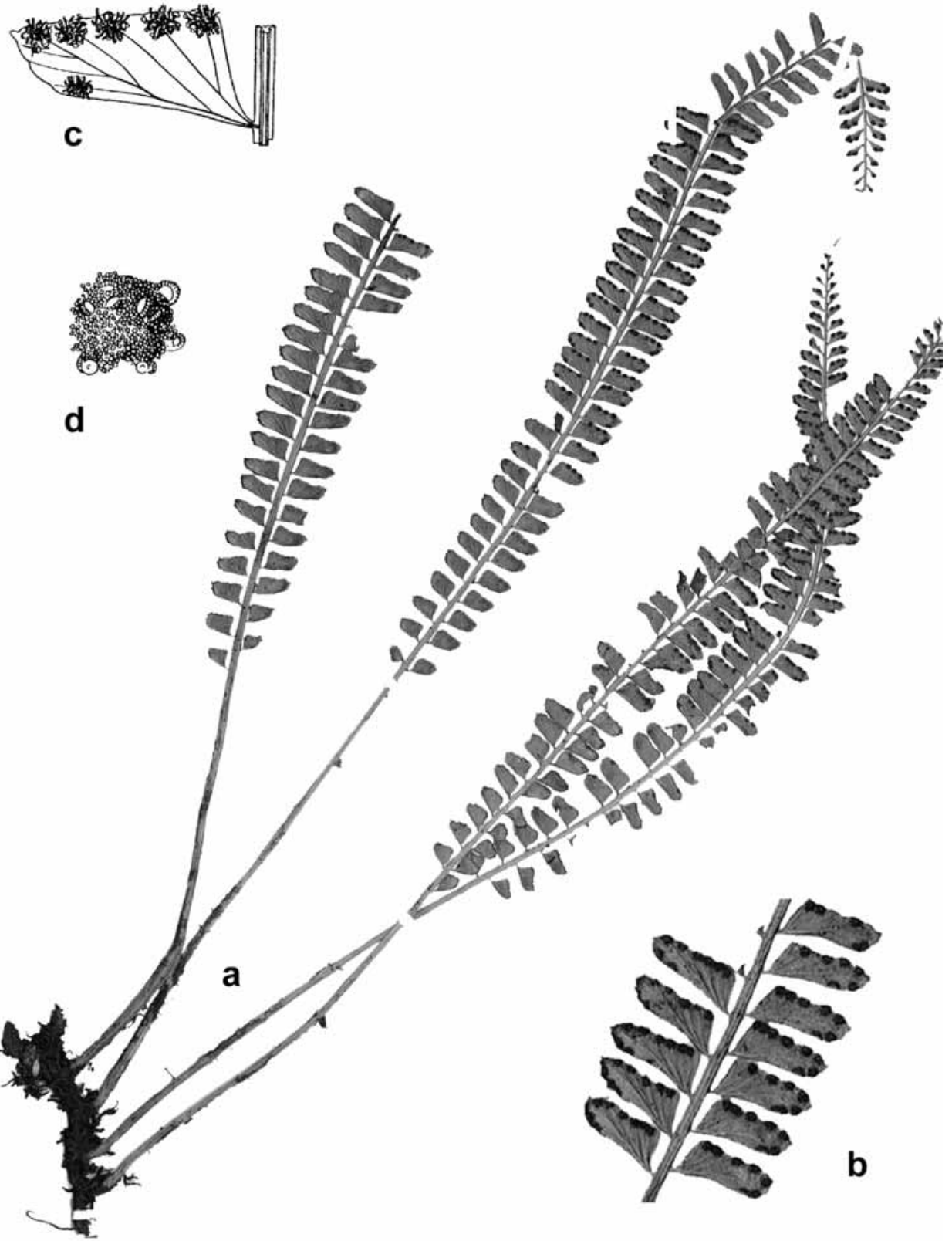

Fig. 2. Rheopteris cheesmaniae Alston, the sole representative of the monotypic (and Malesian endemic) genus Rheopteris: a, scan of the most recent collection of this species: Croft 1749 collected in the West Sepik Province of Papua New Guinea in 1982 (Duplicates LAE, K, L, NSW, CHR, A illustrated here); length of rhizome fragment, $7.5 \mathrm{~cm}$; length of longest frond, $44 \mathrm{~cm}$; note that the frond on the left is incomplete and a $4.5 \mathrm{~cm}$ section near the tip of the longest frond has been turned over to reveal the dorsal surface; although it is not obvious, this section of the frond is also fertile; b, magnified portion of a frond showing pinnules similar in shape to those of Lindsaea and round, exindusiate, sori; pinnules c. $1.2-1.4 \mathrm{~cm}$ long, c. $0.5 \mathrm{~cm}$ broad; c, illustration of a pinnule showing the free venation and the position of the sori in relation to these; $d$, illustration of a sorus (c. $0.1 \mathrm{~cm}$ diameter), typically composed of more paraphyses than sporangia. Illustrations (c) and (d) drawn by Monica Shaffer-Fehre (Royal Botanic Gardens Kew). These and additional line-drawings of $R$. cheesmaniae (including paraphyses and scales) can be found in Johns (1995). 
and that of Croft 1716 (duplicate at A with rhizome fragment $13.5 \mathrm{~cm}$ long) states' ... climbing epiphyte ...' but as with the type specimen there is insufficient material or comments on the labels to understand the original growth habit of the plants. According to the label on the type specimen, Cheesman's plant was growing on the trunk of a fallen tree that was lying in a fast-flowing mountain stream at approximately $600 \mathrm{~m}$. This description does not specifically say whether the plant was in the water, or could have been when the stream was in spate, but it appears that Alston interpreted Cheesman's description as implying a rheophytic existence and this (according to Holltum (1962), though Alston (1956) himself did not say so) is the origin of the name Rheopteris. Croft's specimen labels are much more informative than Cheesman's and they reveal, beyond any doubt, that $R$. cheesmaniae is not a rheophyte. Croft 1716 was discovered as a climbing epiphyte close to (but not in) a stream in mixed lowland hill forest at c. $300 \mathrm{~m}$; Croft 1749 was even more distant from a rheophytic existence; it was discovered climbing on a small tree in naturally disturbed montane forest on an exposed summit ridge at c. $1100 \mathrm{~m}$.

It is worth noting that a second species of Rheopteris (also from New Guinea and perhaps a true rheophyte), was described by Holttum (1962). This species (R. asplenioides Holttum) remained in the genus Rheopteris for only 13 years before Hennipman (1975) decided that it was better placed in the genus Austrogramme (Pteridaceae), section Aspleniopsis (Tryon et al. 1990). Austrogramme asplenioides (Holttum) Hennipman was renamed Aspleniopsis asplenioides (Holttum) Pic.Serm. in 1977 (Pichi-Sermolli 1977).

Tryon and Lugardon (1990) compared spores from the type specimen of $R$. cheesmaniae (wrongly cited by them as being at L but there is no isotype there) with those from Croft 1716 and noted a size difference. Spores from the type specimen have a diameter of approximately $50 \mu \mathrm{m}$ whereas those from Croft 1716 have a diameter of approximately $40 \mu \mathrm{m}$. Tryon and Lugardon concluded that this size difference could be an indication of different ploidy levels within the species but until new plants are discovered and living material is collected, cytological analysis and investigation of possible ploidy differences by traditional methods is not possible. Reports of forest destruction in the West Sepik region (due to logging and invasive plant species; B. Waterhouse, pers. comm.) make the rediscovery of $R$. cheesmaniae and the collection of living material and ecological data all the more urgent.

\section{Independent gametophytes}

The term 'independent gametophyte' is used in Pteridology to describe a situation in which the gametophyte generation of a particular fern species has established, and is surviving, beyond the known geographical or altitudinal range of the sporophyte generation (Farrar 1985; Rumsey \& Sheffield 1996). To date, all independent gametophytes to which species names have been assigned (not an easy task - see Farrar (1978) and below) are members of three families; the Hymenophyllaceae, Grammitidaceae and the Vittariaceae, but it is not yet clear whether gametophytic independence is characteristic of these families or of only certain genera or species within them.

Currently, independent gametophytes are known: in nine species of the Hymenophyllaceae in four genera (Hymenophyllum, Mecodium, Trichomanes, and Callistopteris); in the Grammitidaceae one species in one genus (Grammitis, Xiphopteris or Micropolypodium, depending on one's view-point); and in the Vittariaceae two species in one genus (Vittaria). The two species of Vittaria are V. graminifolia Kaulf. and $V$. appalachiana Farrar \& Mickel; independent gametophyte populations of both have been found only in the eastern United States (Farrar \& Landry 1987; Farrar \& Mickel 1991). 
In spite of the paucity of information on independent gametophytes (and, in particular, the lack of evidence for them in all but one genus of Vittariaceae) there are good reasons to believe that the phenomenon will, with further study, prove to be widespread in this family. The reasons for believing this are three-fold: First, all the gametophytes of Vittariaceae for which at least some published morphological data is available (18 species representing the genera Ananthacorus, Anetium, Hecistopteris, Vittaria, Radiovittaria, Haplopteris, Antrophyum, Polytaenium, Scoliosorus, and Vaginularia; see Goebel 1888, 1896; Britton \& Taylor 1902; Troll 1932; Stokey 1951; Atkinson \& Stokey 1964; Farrar 1974, 1978; and Crane 1997) are ribbon-shaped with multiple marginal meristems that frequently dichotomize (gametophytes of most fern species are heart-shaped, unless old or damaged, with a single recessed apical notch meristem). These features are consistent with a creeping, branching, mat or weftforming habit and a perennial existence. Second, gametophytes of all but one of the 18 species known (the exception being Ananthacorus angustifolius (Sw.) Underw. \& Maxon) also produce gemmae by which they can propagate themselves asexually (Goebel 1888 and 1896; Troll 1932; Britton \& Taylor 1902; Hughes 1971; Emigh \& Farrar 1977; Farrar 1974 \& 1978; Sheffield \& Farrar 1988; Crane 1997). Reproduction by gemmae enables the gametophyte generation of any species to maintain a presence (and a particular genotype) in a new area, beyond that currently tolerated by the sporophyte generation, even if the original colonizing gametophyte does eventually die. Third, independent gametophytes either confirmed (only for V. graminifolia and $V$. appalachiana) or suspected to be those of Vittariaceae have already been reported from the eastern United States, Mexico, Central America, Hawaii, Japan, and northern India (Farrar 1985). As yet, there appear to be no published reports of even the suspected presence of independent gametophytes of Vittariaceae (nor of any other fern family) in South America, Africa, or tropical Asia (including the entire Flora Malesiana region). While there could be a good biological explanation for this, it seems more likely that the apparent absence of independent gametophytes from the regions of the world where ferns in general are most common (and, therefore, where conditions for fern gametophyte establishment must often be favorable) is simply an artifact resulting from inadequate field observations and collections in these regions.

Even if, as suggested by Rumsey and Sheffield (1996), gametophyte independence proves to be more prevalent in species growing at the temperate extremes of this family's largely tropical distribution, the environmental factors that help create the phenomenon in a geographical context might also be expected to operate in an altitudinal context. With this in mind, it might be particularly fruitful to focus initial searches for independent gametophytes in Malesia along an altitudinal gradient incorporating the transition zones between tropical, subtropical, and temperate habitats. It must be emphasized that when independent gametophytes suspected of being Vittariaceae are eventually found in Malesia they will not be easily or quickly identified to species. Confident identification to species may require that the gametophytes be collected alive and cultured long enough to produce identifiable sporophytes. However, there is no guarantee that independent gametophytes will produce sporophytes even in prolonged culture (see below). Identification of independent gametophytes based solely on gametophytic characters would require considerable knowledge of the morphology of the gametophytes of all species of Vittariaceae in, and possibly even beyond, the Flora Malesiana region.

It should not be assumed that any independent gametophytes found in the Flora Malesiana region are those of one of the nearest species represented by sporophytes. Vittaria graminifolia, one of the two Vittaria species currently confirmed as having independent gametophytes, is known in the United States (in Louisiana), only as gametophytes and the nearest known population of sporophytes is more than $1000 \mathrm{~km}$ away in Mexico (Farrar \& Landry 1987; Gastony 1980). Similar distances are reported to 
separate the independent gametophytes of other fern species [e.g. Grammitis nimbata (Jenman) Proctor and Trichomanes speciosum Willd.] from their nearest known sporophytes (Farrar 1967; Rumsey \& Sheffield 1996; F. Rumsey, pers. comm.). It is therefore quite possible that the number of fern species growing on the individual islands in Malesia is actually more than that which is indicated by recording species numbers by sporophyte presence alone. It is also possible that living within the Flora Malesiana region are gametophytes of species not recorded as sporophytes from the region.

One technique that has been used very successfully in the identification of independent gametophytes, and of other morphologically indistinguishable gametophytes (e.g. Lindsay et al. 1992), is isozyme electrophoresis (e.g. Farrar 1985, 1992a, 1992b). Provided that appropriate reference samples are analyzed at the same time this technique can be used to generate and compare isozyme 'finger-prints', and thereby identify or, at least, considerably narrow the search for the identity of morphologically indistinguishable fern gametophytes. For example, the isozyme finger-print of the independent gametophytes found in Louisiana was found to be identical to the isozyme finger-print of those already known to be Vittaria graminifolia from Central America and this fact, combined with comparative studies of gametophyte morphology and gemma development, led to the discovery of the true identity of these independent gametophytes (Farrar \& Landry 1987).

The discovery of the identity of the only other Vittaria species currently confirmed as having independent gametophytes, Vittaria appalachiana, was much more complicated (Farrar 1978), so complicated that it was not assigned a species name until 1991, some 60 years after its discovery (Wagner \& Sharp 1963; Farrar \& Mickel 1991). The main difficulty with attempts to identify this species was that no sporophyte generation could be located and no sporophytes could be raised from cultured gametophytes even under a range of experimental conditions. After years of careful morphological, genetic, and biochemical comparisons with a range of New World (mostly Central American) Vittaria, it was eventually concluded that these independent gametophytes from the Appalachians were significantly different from those of all the other species examined and that, quite remarkably, they probably represent the gametophyte generation of an unknown species of Vittaria whose sporophyte generation has long since gone extinct (Farrar \& Mickel 1991). Vittaria appalachiana Farrar \& Mickel was the first extant fern species (cf. certain early-Devonian land plants; Remy et al. 1993) to be described based solely on a description of the gametophyte generation. Since then two other species of independent fern gametophytes also with no known sporophytes have been described. These are Hymenophyllum tayloriae Farrar and Raine and Trichomanes intricatum Farrar (Raine et al. 1991; Farrar 1992b).

\section{Conclusion}

Although Crane's sampling of African and Asian Vittariaceae was somewhat limited, the results and conclusions of his molecular study have seriously challenged the traditional concepts of Vittaria and Antrophyum as two large pantropical genera. If Crane's conclusions are accepted then Vittaria s.s. is, in fact, confined (with the exception of one species) to the New World and Antrophyum s.s. is confined (with no exceptions) to the Old World. In practice, acceptance of these conclusions will not affect the revision of Antrophyum for Flora Malesiana but it will significantly affect the revision of all the Malesian species traditionally regarded as Vittaria (20-30 species; Table 1). Eleven Malesian 'Vittaria' species have already been re-classified by Crane including those as well known as: Vittaria elongata Sw. (now Haplopteris elongata (Sw.) E.H.Crane); Vittaria ensiformis Sw. (now Haplopteris ensiformis (Sw.) E.H.Crane); Vittaria scolopendrina (Bory) Schkuhr ex Thwaites \& Hook. (now Haplopteris scolopendrina 

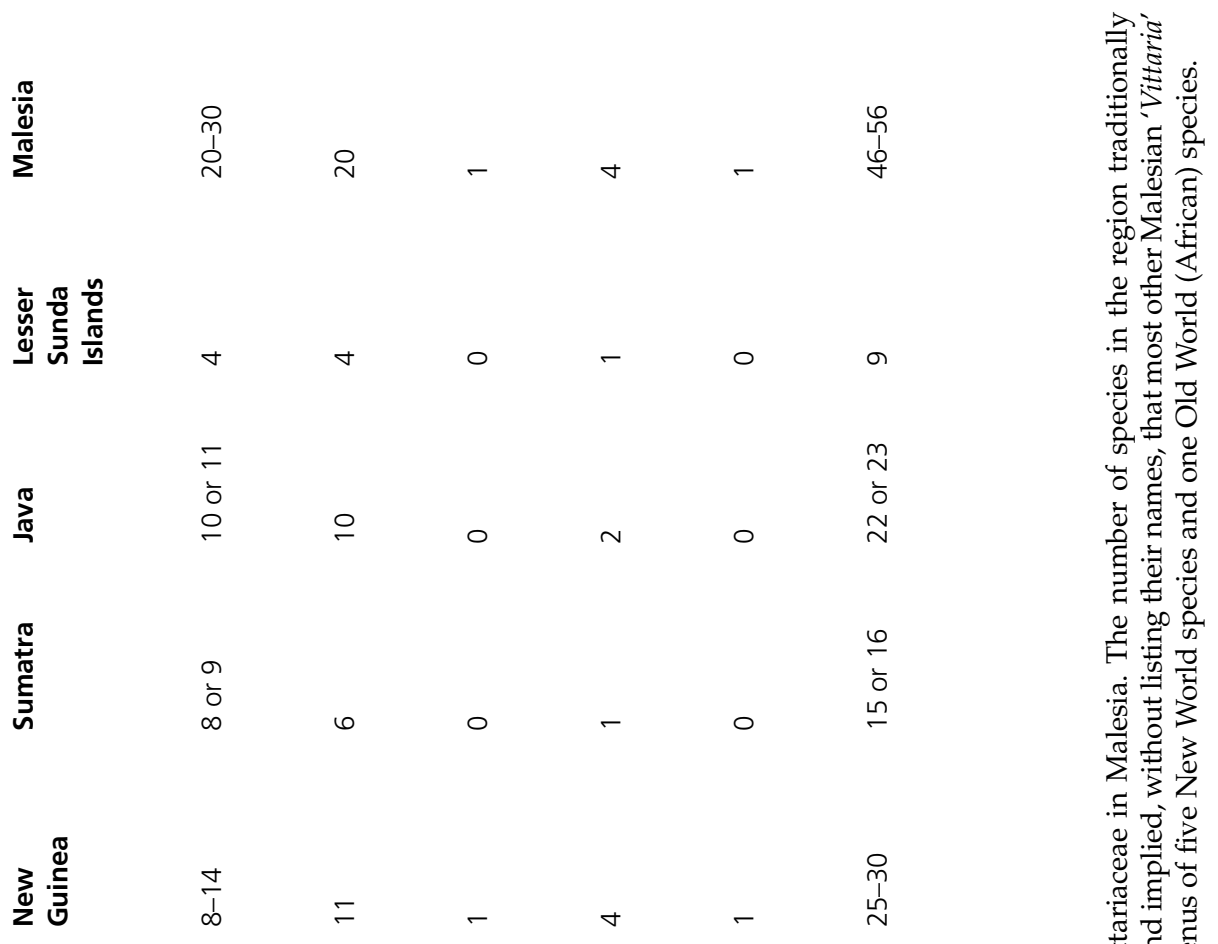

胥远

. द्व

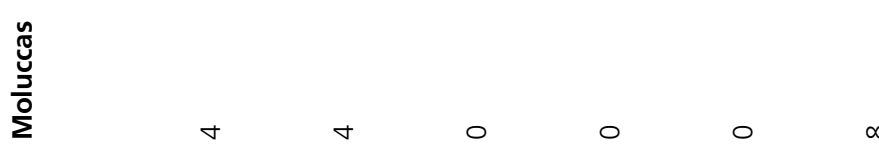

$\bar{\Phi}$
$\frac{\overline{0}}{5}$
$\frac{10}{5}$

ธิ

웅

$\exists$ \&

$\stackrel{+}{+}$

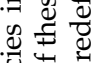

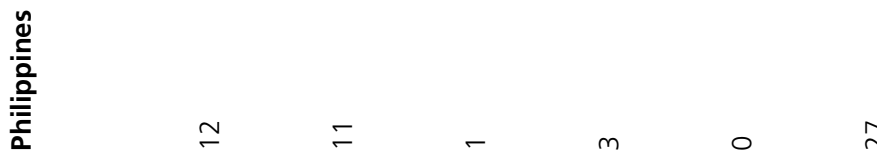

ơ

पे

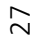

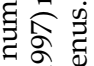

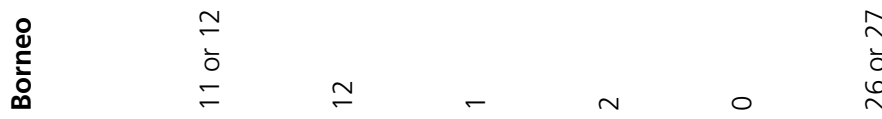

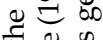

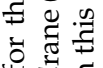

政

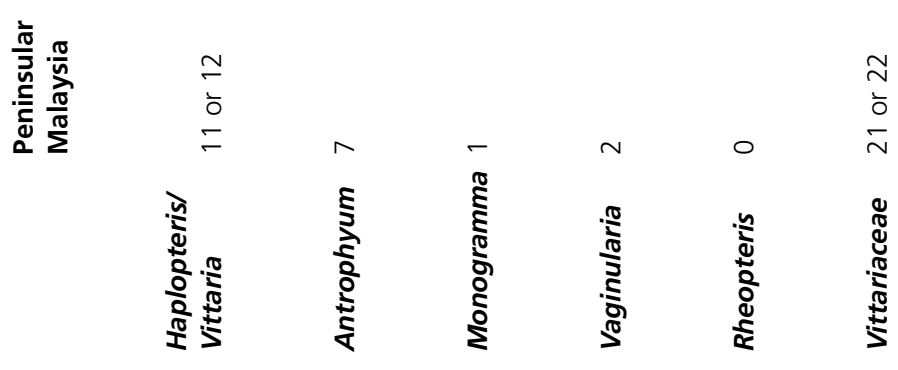

ชั

चै त

is 0

额.

द 50

원

政

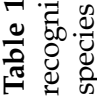


(Bory) C.Presl); and Vittaria zosterifolia Willd. (now Haplopteris zosterifolia (Willd.) E.H.Crane). Decisions on whether other Malesian 'Vittaria' species should be moved to Haplopteris, moved elsewhere, or treated as synonyms, will be dependent on the outcome of a thorough comparison of micro-morphological characters. The generation and comparison of new molecular characters, including additional $r b c L$ sequence data for a more representative selection of Malesian species and genera, is also highly desirable. Molecular characters could be the key to determining the correct taxonomic position of the monotypic (and Malesian endemic) genus Rheopteris.

Independent gametophytes have not yet been reported from the Malesian region but there are good reasons to believe that, with more careful and focused field observations, they will eventually be found. In spite of the novel and important contribution that the confirmed presence and subsequent identification of independent gametophytes would make to our understanding of species numbers and their distribution within Malesia they will not feature in the first account of Vittariaceae for Flora Malesiana. This first account, like the accounts of most fern families in most Floras, will be based almost exclusively on sporophytic data. In reality, a description (with distribution data) of all the fern species present as sporophytes in Malesia is a prerequisite for any future attempts to study and identify independent gametophytes. It is likely to be a long time before any revision of the Vittariaceae (in Malesia or elsewhere) gives a balanced account of both the gametophyte and sporophyte generations.

\section{Acknowledgments}

I would like to thank Dr R. Cook (Director of the Arnold Arboretum of Harvard University) and Dr D. Pfister (Director of Harvard University Herbaria), for giving me the opportunity to pursue my research interests at Harvard and for making my participation at the $5^{\text {th }}$ Flora Malesiana Symposium possible. I am also grateful to Dr A.R. Smith (University of California) and Dr D. Middleton (Harvard University) for their insightful comments on earlier versions of this paper.

\section{References}

Alston, A.H.G. (1956) Some undescribed ferns from New Guinea and Ambon. Nova Guinea, new series 7(1): 1-3.

Atkinson, L.R. \& Stokey, A.G. (1964) Comparative morphology of the gametophyte of homosporous ferns. Phytomorphology 14: 51-70.

Benedict, R.C. (1907) The genus Antrophyum - I. Synopsis of subgenera, and the American species. Bulletin of the Torrey Botanical Club 34(9): 445-458.

Benedict, R.C. (1911) The genera of the fern tribe Vittarieae: their external morphology, venation and relationships. Bulletin of the Torrey Botanical Club 38(4): 153-190.

Benedict, R.C. (1914) A revision of the genus Vittaria J. E. Smith. I. The species of the subgenus Radiovittaria. Bulletin of the Torrey Botanical Club 41(8): 391-410.

Britton, E.G. \& Taylor, A. (1902) The life history of Vittaria lineata. Memoirs of the Torrey Botanical Club 8: 185-220.

Brummitt, R.K. (1992) Vascular plant families and genera. (Royal Botanic Gardens: Kew).

Christensen, C. (1905-1906) Index Filicum (1753-1905). (Copenhagen).

Christensen, C. (1913) Index Filicum - Supplementum (I) (1906-1912). (Copenhagen).

Christensen, C. (1917) Index Filicum - Supplementum (II) (1913-1916). (Copenhagen).

Christensen, C. (1925) Fougères de Madagascar récoltes de M.H. Perrier de la Bathie. Notes Ptéridologiques 16: 11-153.

Christensen, C. (1934) Index Filicum - Supplementum tertium (1917-1933). (Copenhagen).

Copeland, E.B. (1947) Genera Filicum. (Chronica Botanica Company, Waltham: Mass.). 
Crane, E.H. (1995) A molecular phylogenetic study of the fern family Vittariaceae, Ph.D. Thesis, (Iowa State University, Ames: Iowa).

Crane, E.H. (1997) [actually published January 1998]. A revised circumscription of the genera of the fern family Vittariaceae. Systematic Botany 22(3): 509-517.

Crane, E. H., Farrar, D.R. \& Wendel, J.F. (1995) Phylogeny of the Vittariaceae: convergent simplification leads to a polyphyletic Vittaria. American Fern Journal 85(4): 283-305.

Emigh, V.D. \& Farrar, D.R. (1977) Gemmae: A role in sexual reproduction in the fern genus Vittaria. Science (New York) 198: 297-298.

Farrar, D.R. (1967) Gametophytes of four tropical fern genera reproducing independently of their sporophytes in the southern Appalachians. Science (New York) 155: 1266-1267.

Farrar, D.R. (1974) Gemmiferous fern gametophytes - Vittariaceae. American Journal of Botany 61(2): $146-155$.

Farrar, D.R. (1978) Problems in the identity and origin of the Appalachian Vittaria gametophyte, a sporophyteless fern of the eastern United States. American Journal of Botany 65(1): 1-12.

Farrar, D.R. (1985) Independent fern gametophytes in the wild. Proceedings of the Royal Society of Edinburgh 86B: 361-369.

Farrar, D.R. (1992a) Identification and ecology of gametophytes of Hawaiian Hymenophyllaceae. American Journal of Botany 79: 118.

Farrar, D.R. (1992b) Trichomanes intricatum: the independent Trichomanes gametophyte in the Eastern United States. American Fern Journal 82(2): 68-74.

Farrar, D.R. and Landry, G.P. (1987) Vittaria graminifolia in the United States, again. American Journal of Botany 74: 709.

Farrar, D.R. \& Mickel, J.T. (1991) Vittaria appalachiana: a name for the 'Appalachian gametophyte'. American Fern Journal 81(3): 69-75.

Fée, A.L.A. (1852a) Histoire des Vittariées et des Pleurogrammées: Troisième Mémoire. Pp. 1-38 in Mémoires sur la Famille des Fougères. Paris.

Fée, A.L.A. (1852b) Histoire des Antrophyées: Quatrième Mémoire. Pp. 39-52 in Mémoires sur la Famille des Fougères. Paris.

Gastony, G.J. (1980) The deletion of Vittaria graminifolia from the Flora of Florida. American Fern Journal 70(1): 12-14.

Goebel, K. (1888) Morphologische und Biologische Studien. II Zur Keimungsgeschichte einiger Farne. Annales du Jardin Botanique de Buitenzorg 8: 74-119.

Goebel, K. (1896) Archegoniatenstudien. 8. Hecistopteris, eine verkannte Farngattung. Flora 82: $67-75$.

Hennipman, E. (1975) A re-definition of the gymnogrammoid genus Austrogramme Fournier. Fern Gazette 11(2 \& 3): 61-72.

Holttum, R.E. (1962) New species of Malaysian ferns. Blumea 11(2): 529-534.

Hughes, S.J. (1971) On conidia of fungi, and gemmae of algae, bryophytes, and pteridophytes. Canadian Journal of Botany 49: 1319-1339.

Jarrett, F.M. (1985) Index Filicum - Supplementum quintum (1961-1975). (Clarendon Press: Oxford).

Johns, R.J. (1995) Endemism in the Malesian Flora. Curtis's Botanical Magazine 12(2): 95-110.

Johns, R.J. (1996) Index Filicum - Supplementum sextum (1976-1990). Royal Botanic Gardens: Kew).

Johns, R.J. (1997) Index Filicum - Supplementum septimum (1991-1995). (Royal Botanic Gardens: Kew).

Kellof, C.L. \& McKee, G.S. (1998) A new species of Hecistopteris from Guyana, South America. American Fern Journal 88(4): 155-157.

Kramer, K.U. (1990) Vittariaceae. Pp. 272-277 in K.U. Kramer \& P.S. Green (eds), The families and genera of vascular plants. I. Pteridophytes and gymnosperms. (Springer-Verlag: Berlin).

Lindsay, S., Sheffield, E. and Dyer, A.F. (1992). Soil spore banks, fern conservation and isozyme analysis. Pp. 279-283 in Fern horticulture: past, present and future perspectives. (Intercept Ltd.: Andover).

Maxon, W.R. (1908) Studies of tropical American ferns. No. 1. Contributions from the United States National Herbarium 10(7): 486-487.

Moore, T. (1857) Index Filicum: a synopsis with characters of the genera and an enumeration of the species of ferns. (William Pamplin: London).

Moran, R.C. (1995) Vittariaceae. Pp. 145-150 in G. Davidse, S.M. Sousa, \& S. Knapp (eds), Flora Mesoamericana Volume 1. (Universidad Nacional Autónoma de México, Missouri Botanical Garden and The Natural History Museum: London).

Moran, R.C. \& Øllgaard, B. (1995) Six new species of ferns (Polypodiopsida) from Ecuador. Nordic Journal of Botany, 15(2): 177-185. 
Nayar, B.K. \& Kaur, S. (1969). Types of prothallial development in homosporous ferns. Phytomorphology 19: 179-188.

Nayar, B. K. \& Kaur, S. (1971) Gametophytes of homosporous ferns. Botanical Review 37(3): 295-396.

Pichi-Sermolli, R.E.G. (1965) Index Filicum - Supplementum quartum (1934-1960. (International Bureau for Plant Taxonomy and Nomenclature: Utrecht).

Pichi-Sermolli, R.E.G. (1977) Fragmenta Pteridologiae - VI. Webbia 31(1): 237-259.

Raine, C.A., Farrar, D.R. \& Sheffield, E. (1991) A new Hymenophyllum species in the Appalachians represented by independent gametophyte colonies. American Fern Journal 81(4): 109-118.

Remy, W., Gensel, P.G. \& Hass, H. (1993) The gametophyte generation of some early Devonian land plants. International Journal of Plant Sciences 154(1): 35-58.

Rumsey, F.J. \& Sheffield, E. (1996) Inter-generational ecological niche separation and the 'independent gametophyte' phenomenon. Pp. 563-570 in J.M. Camus, M. Gibby \& R.J. Johns (eds), Pteridology in Perspective. (Royal Botanic Gardens: Kew).

Shaffer-Fehre, M. (1996) A preliminary investigation of the paraphyses of Vittaria (Vittariaceae) Pp. 531-534 in J.M. Camus, M. Gibby \& R.J. Johns (eds), Pteridology in Perspective. (Royal Botanic Gardens: Kew).

Sheffield, E. \& Farrar, D.R. (1988) Cryo SEM examination of gemma formation in Vittaria graminifolia. American Journal of Botany 75(6): 894-899.

Stokey, A.G. (1951) The contribution by the gametophyte to classification of the homosporous ferns. Phytomorphology 1: 39-58.

Troll, von W. (1932) Botanische Mitteilungen aus den Tropen. IV. Brutkörper bildende Prothallien bei Antrophyum callaefolium Blume. Flora 126: 371-379.

Tryon, A.F. \& Lugardon, B. (1990) Spores of the Pteridophyta. (Springer-Verlag: New York, Berlin, Heidelberg, London, Paris, Tokyo, Hong Kong, Barcelona).

Tryon, R.M. \& Tryon, A.F. (1982) Ferns and allied plants with special reference to tropical America. (Springer-Verlag: New York).

Tryon, R.M., Tryon, A.F. \& Kramer, K.U. (1990) Pteridaceae. Pp. 230-240 in K.U. Kramer \& P.S. Green (eds), The families and genera of vascular plants. I. Pteridophytes and gymnosperms. (Springer-Verlag: Berlin).

Wagner, W.H.Jr. \& Sharp, A.J. (1963) A remarkably reduced vascular plant in the United States. Science (New York) 142: 1483-1484.

Willams, S. (1927) A critical examination of the Vittarieae with a view to their systematic comparison. Transactions of the Royal Society of Edinburgh 55: 173-217. 